\title{
Increasing the Training Set in Face Recognition Tasks by Using a 3D Model of a Face
}

\author{
Olga Krutikova ${ }^{1}$, Aleksandrs Glazs ${ }^{2},{ }^{1,2}$ Riga Technical University
}

\begin{abstract}
The paper proposes a method for face recognition, which uses a 3D model of the head, which is turned at different angles to extend the size of the training set. Control points are placed on the images, which have been created using the 3D model of the head, and the distance ratios between the control points are stored in the database. Face recognition algorithm would look for two images of faces in the data base which have minimal difference between the turn angles of the head and the distance ratios.
\end{abstract}

Keywords-Face recognition, polygonal model, 3D model, training set.

\section{INTRODUCTION}

Face recognition is widely used in image recognition theory. For example, identification of a person by the image of his face can be used in identification control systems (passport, driving license), information security (access to computers, databases, etc.), observation and investigation of criminal events, as well as in banking (ATM, remote account management).

There are many face recognition methods, for example, principal component analysis (PCA) [1], [2]. This has become known as the eigenface algorithm and is now a golden standard in face recognition. But it has a significant problem certain conditions are required, like proper lighting, neutral face expression, absence of beard and glasses.

Another example of 2D face recognition - method of Viola-Jones [3], [4], [5] works well with images of faces turned by less than $30^{\circ}$ away from the camera, but unfortunately is useless for images of faces rotated by arbitrary angle.

There is also significant number of papers on the identification of people by portrait photos [6], [7], [8], [9], [10]. In this case, the term "photograph" means a digital image of a full face without elements of clothing, jewellery, sunglasses, etc., which may cover or distort the face.

Furthermore, all the 2D (image-based) face recognition methods are sensitive to illumination conditions, head orientation, facial expression and makeup. Also many of the existing 2D face recognition algorithms could not be used to identify a face, because the input information about the shape of the face consists of minimal training sample - an image of a full face, a profile and a half-turn. Creating a threedimensional model of a face based on the input images allows rotation of the model at different angles, thus increasing the training sample, which allows to retrieve missing information about the shape of the face, which later could be used for further analysis which could increase the precision of face recognition.
Therefore, in our previous works [11] and [12] we have described an approach for creating a polygonal 3D model of a head (Fig. 1), constructed by using the three base images (profile, front, half-turn). This method adapts the 3D model of a head by using manually placed control points in several projections and places texture on the adapted model.

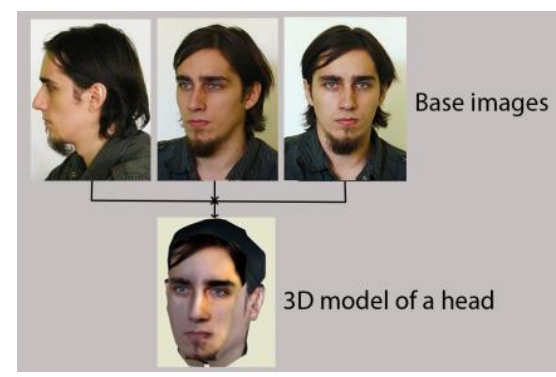

Fig. 1. Approach for creation of polygonal 3D model of a head.

In this paper, we propose a method for using the mentioned polygonal 3D model in the face recognition algorithm.

\section{II.PROPOSED METHOD}

A block diagram of the face recognition algorithm is shown in Fig. 2.

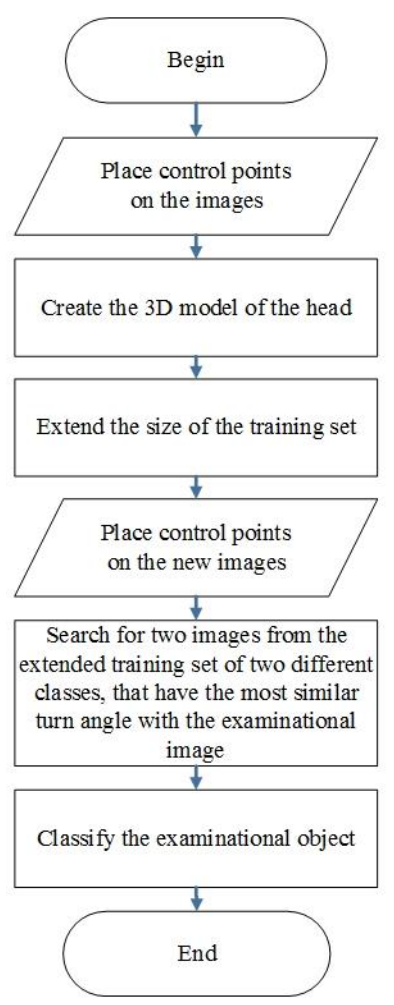

Fig. 2. Block diagram of the proposed face recognition algorithm. 
The proposed method consists of several steps:

a) creating the $3 \mathrm{D}$ model of a head by using three base images;

b) extending the size of the training set by generating new 2D images of a face, that are based on the created 3D model;

c) searching for two images from the extended training set of two different classes, that have the most similar turn angle with the examinational image;

d) determining the examinational object's "closest neighbor" among the two images (classification of the examinational object).

\section{A. Creating a 3D Model of a Head}

For creating a 3D model of a head we used 6 base photographic images (Fig. 3) of two similarly looking people ( 3 photos of each person: front, half-turn and profile) as input data (training set)

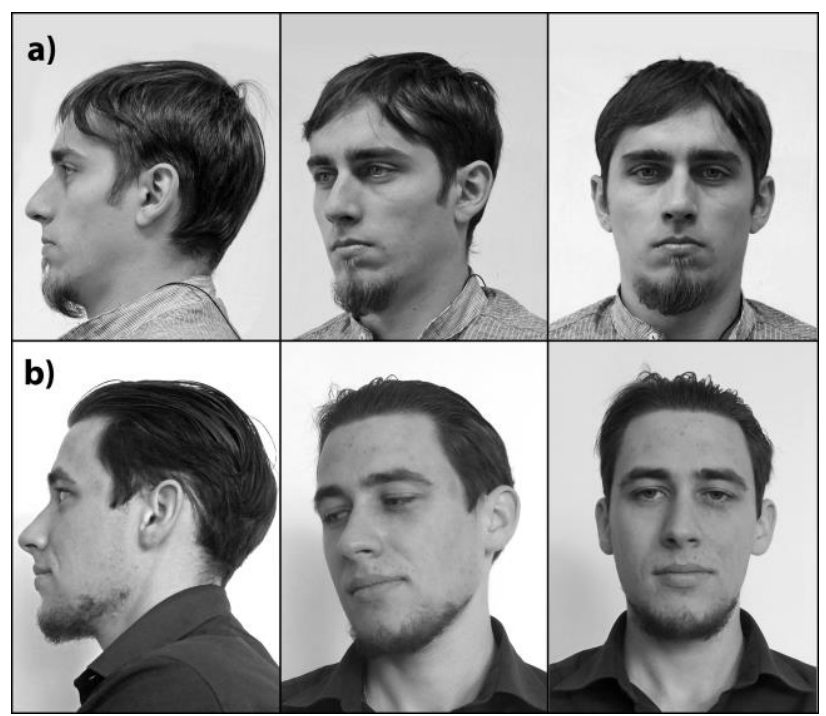

Fig. 3. Training set which consists of two classes: a) first class, b) second class.

For testing the face recognition algorithm results we used 8 photographic images of two people as examinational training set (see Fig. 4).

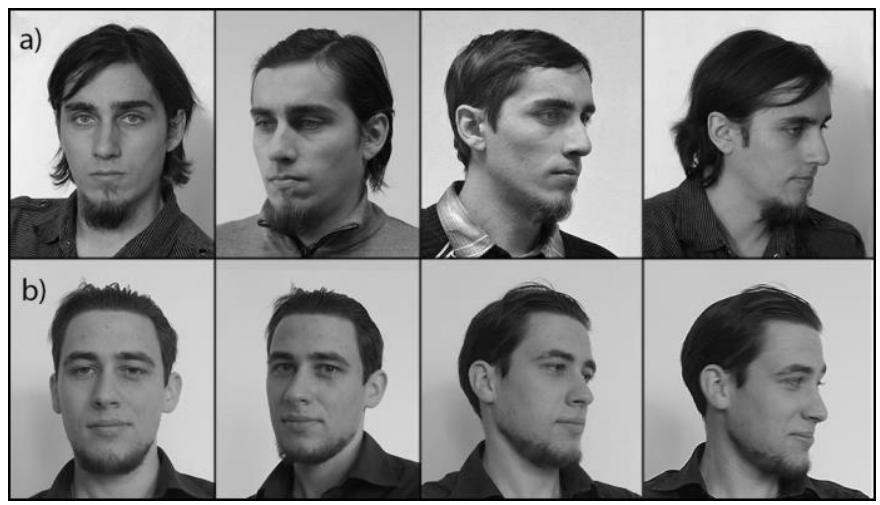

Fig. 4. Examinational training set which consists of two classes: a) first class; b) second class.
The difference from the approach described in [11], [12] is that we propose to use a different method for acquiring and processing the face texture, consequently removing the unnecessary details (hair and beard). A block diagram of the new approach of processing image texture is shown in Fig. 5.

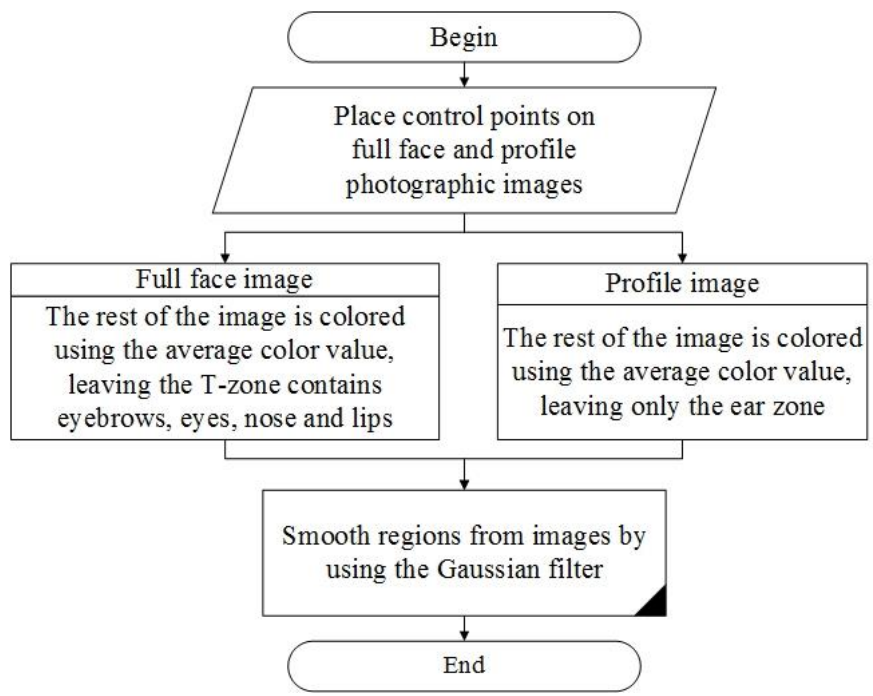

Fig. 5. Block diagram of the proposed method for processing the face texture.

Texture processing algorithm.

1) We first processed the base frontal and profile photographic images (See Fig. 6 a), b)). We only needed information about the part of the face containing eyebrows, eyes, nose and lips - T-zone, the rest of the image was colored using the average color value, as in (1), which was obtained in the nostril area (Fig. 6 c), d)).

$$
I(x, y)=\frac{1}{3}\left[I\left(p_{6}, p_{7}\right)+I\left(p_{7}, p_{7}\right)+I\left(p_{7}, p_{8}\right)\right],
$$

where $I(x, y)$ is current pixel intensity and $p_{6}, p_{7}, p_{8}$ is control point number.

2) Furthermore, the image acquired by such pre-processing was smoothed by using the Gaussian filter [13], as in (2).

$$
G(u, v)=\frac{1}{2 \pi \sigma^{2}} e^{\frac{-\left(u^{2}+v^{2}\right)}{2 \sigma^{2}}},
$$

where

$G(u, v) \quad$ Gaussian distribution;

$\sigma \quad$ standard deviation of distribution;

$u^{2}+v^{2}=r^{2} \quad$ smoothing radius

3) Analogical processing was used for the base profile photographic image (leaving only the ear zone and using the previous average color value as base color for the rest of the image). After such processing, we obtained the final face texture (Fig. 6 e), f)). 


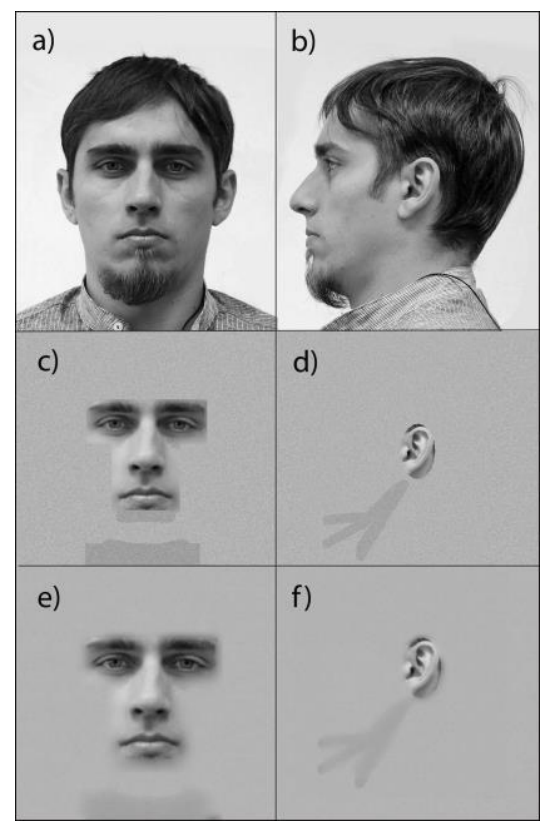

Fig. 6. a) Original frontal image of a face. b) Original profile image of a face. c) Frontal image of a face containing the T-zone after coloring with average color value. d) Profile image of a face containing ear zone after coloring with average color value. e) and f) Resulting images after using Gaussian filter.

Final images of the resulting 3D models of the head are shown in Fig. 7.

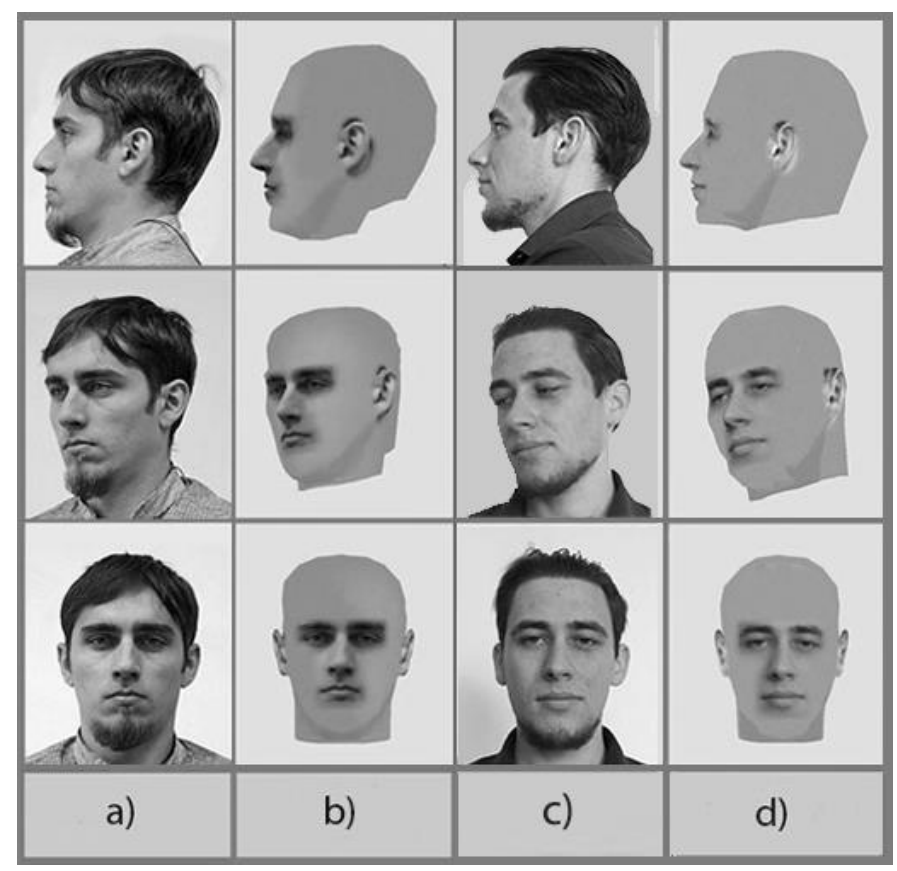

Fig. 7. a) and c) Base images. b), d) Acquired 3D models.

Thereafter, we used such modified polygonal model for the face recognition tasks.

The next step was calculating the distances between some of the control points from the original 3D model, as in (3), using Euclidean distance [14] and $\Delta x$ values as the maximal value of width for each image of the face.

$$
d=\sqrt{\left(x_{2}-x_{1}\right)^{2}+\left(y_{2}-y_{1}\right)^{2}}
$$

$$
\begin{array}{ll}
\text { where } & \\
d & \text { distance between control points; } \\
x_{1}, x_{2}, y_{1}, y_{2} & \text { control point coordinates. }
\end{array}
$$

For example, we can say, that maximal value of width in Fig. $8 \mathrm{c}$ ) is between the two points - point 0 and 1, similarly we can find values for the profile and half-turn images.

The ratio of the distances between the control points was calculated for each photographical image, as in (4)

$$
D_{\text {Ratio }}=\frac{d}{x_{2}-x_{1}},
$$

where $d$ is Euclidean distance and $\Delta x=x_{2}-x_{1}$ is the maximal value of width for each image of the face.

Therefore, the ratio of the distance between the control points was saved in the database as a training sample (Fig. 8.) for face recognition tasks.

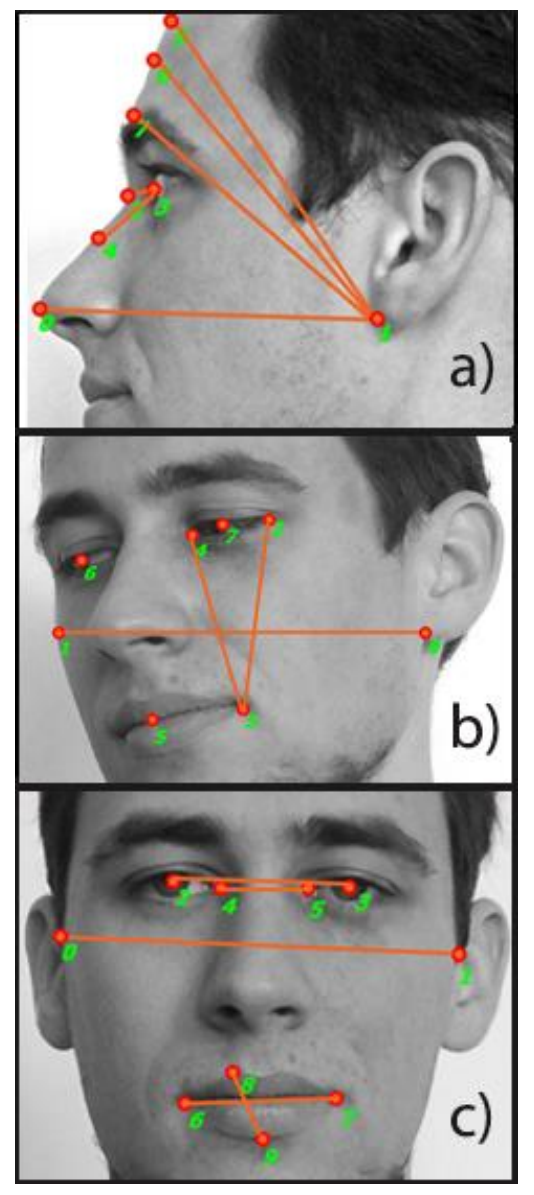

Fig. 8. Ratio of the distance between the control points of a) profile image of the face, b) half-turn image of the face and c) full face image of the face. 
B. Extending the Size of the Training Set by Generating New $2 D$ Images of a Face

The 3D polygonal model was then rotated at different angles $\left(20^{\circ}\right.$ and $\left.50^{\circ}\right)$ to extend the size of the training set with two new 2D images of faces.

We processed every image in the training sample by placing special control points (Fig. 9) which were used as main features during face recognition process and calculating ratios for new images.

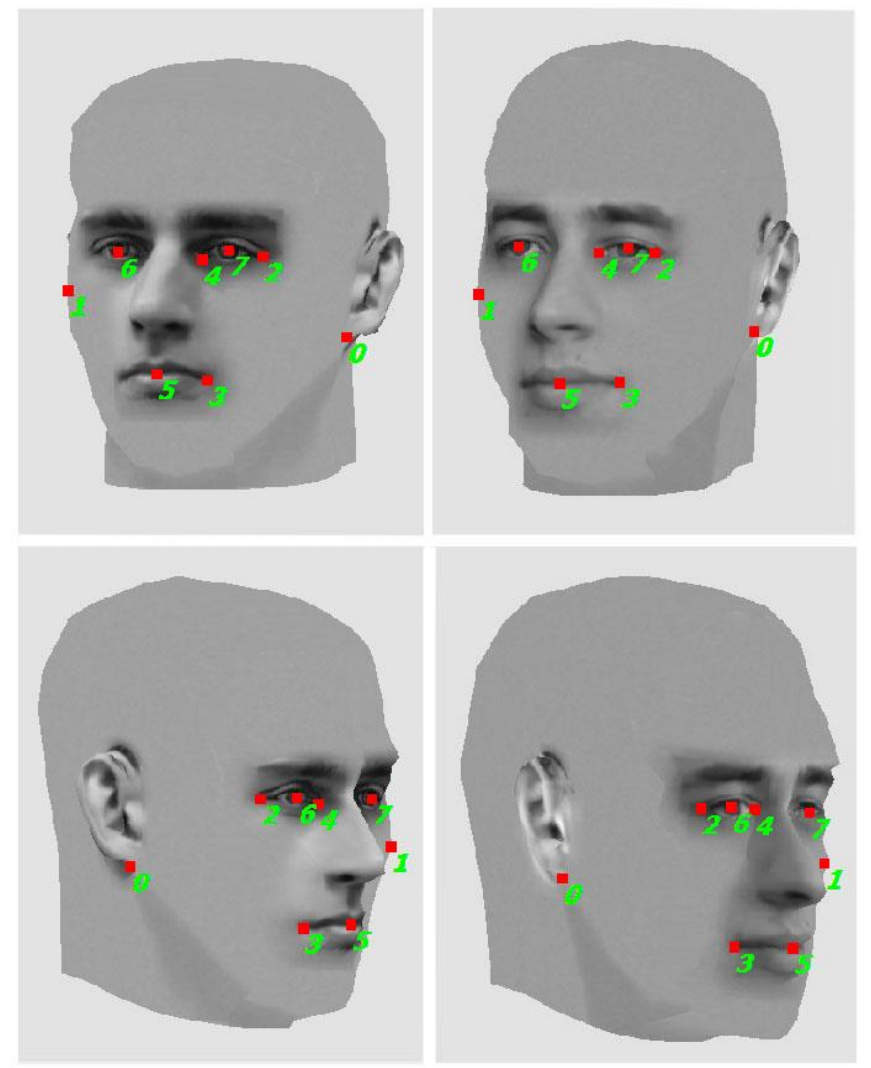

Fig. 9. Images with control points obtained by rotating the $3 \mathrm{D}$ model by 20 and 50 degrees.

\section{Searching for Two Similar Images in the Database}

To perform the third step and to detect the head position on the image, control points were manually placed on the examinational image.

The next step was calculation of ratios between the control points.

Depending on the position of control points, it was possible to determine the orientation of the head. If it was determined that the image shows a turned head and not a profile or full face, the head turn angle was calculated separately.

Block diagram of the head position detection is shown in Fig. 10.

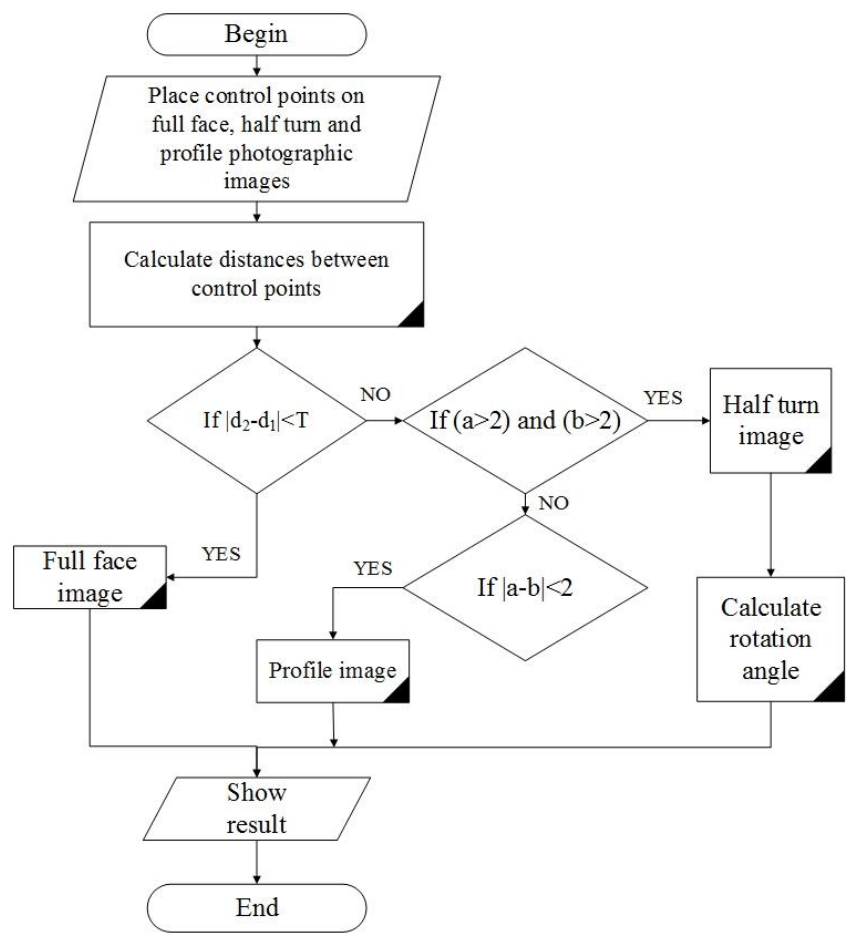

Fig. 10. Block diagram of the head position detection.

Using the control points in Fig. 11 we were able to determine the position of the head, as well as the angle of head's rotation (for half-turn images).

For example, we were calculating distance $d_{1}$ between points 2 and 4 , distance $d_{2}$ between points 3 and 5 using Euclidean distance, like in (3) and $a$ value between points 0 and 1 , and $b$ value between points 2 and 3 .

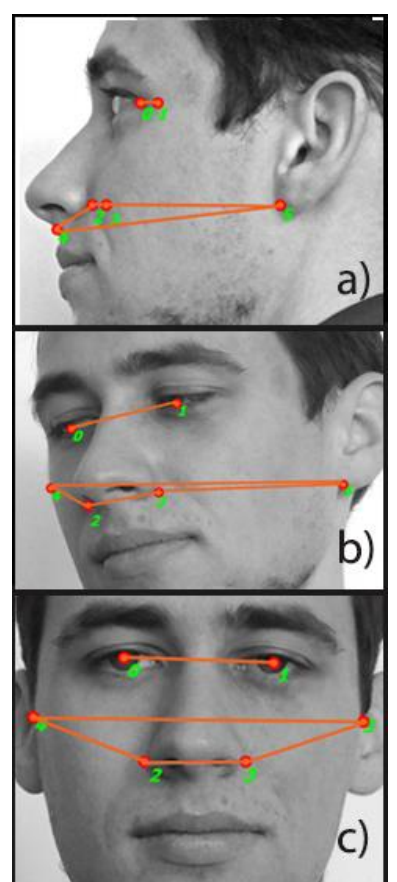

Fig. 11. Placed control points to detect head position for a) profile, b) half-turn image and c) full face image. 
Using the control points we were able to calculate the angle of the head's rotation.

For example, in Fig. 12 a triangle was created using the placed control points. By calculating the angles of it we were able to obtain the angle of the head's rotation.

Head position calculation algorithm.

1) Use the control point coordinates to calculate the edges of the triangle.

2) When the length of the edges is known calculate the angles of the triangle (the cosine rule) [15].

3 ) If the face is turned left then the angle is calculated as in (5) or as in (6) [16]

$$
\begin{aligned}
& \gamma=\frac{\angle A C B-62.75}{0.37} \\
& \beta=\frac{\angle C B A-64.03}{0.33},
\end{aligned}
$$

where $\gamma, \beta$ is head rotation angle and $\mathrm{ACB}$ and $\mathrm{CBA}$ are angles calculated using the Cosine rule.

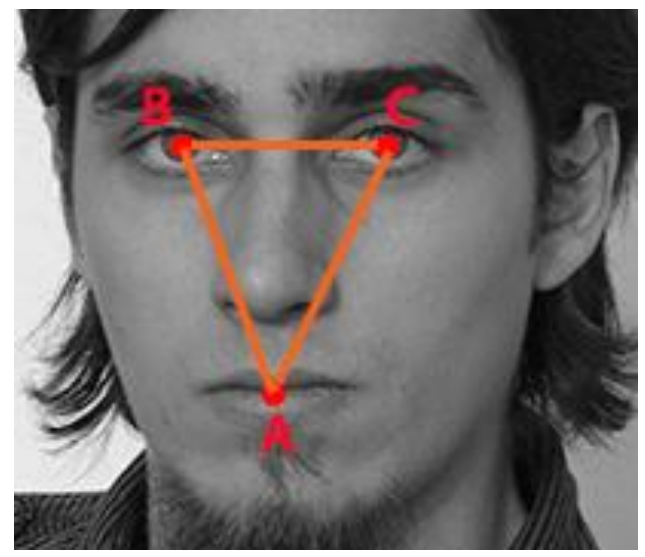

Fig. 12. Triangle created using the placed control points.

4) Show the result - head rotation angle.

\section{Classification of the Examinational Object}

To perform the fourth step, the face recognition algorithm looked for two images of faces in the data base which had minimal difference between the turn angles of the head with the examinational image and one of the two "closest neighbors" was chosen which had minimal difference in distance ratios between the control points, thus classifying (recognizing) the examinational object.

\section{EXPERIMENTS}

For the classification we used 8 additional photographic images of faces turned by an arbitrary angle (examinational sample). At first we used the base training set which contained 3 images (full face, half-turn, and profile) see the results of the algorithm in Fig. 13. Secondly, we used the extended training set which contained 5 images of the face. See the result of the algorithm in Fig. 14.
The use of the extended training sample ( 5 images) allowed to obtain 6 correct recognitions out of 8 images (see Fig. 5). The use of the basic training sample ( 3 images) provided only 5 correct answers out of 8 .

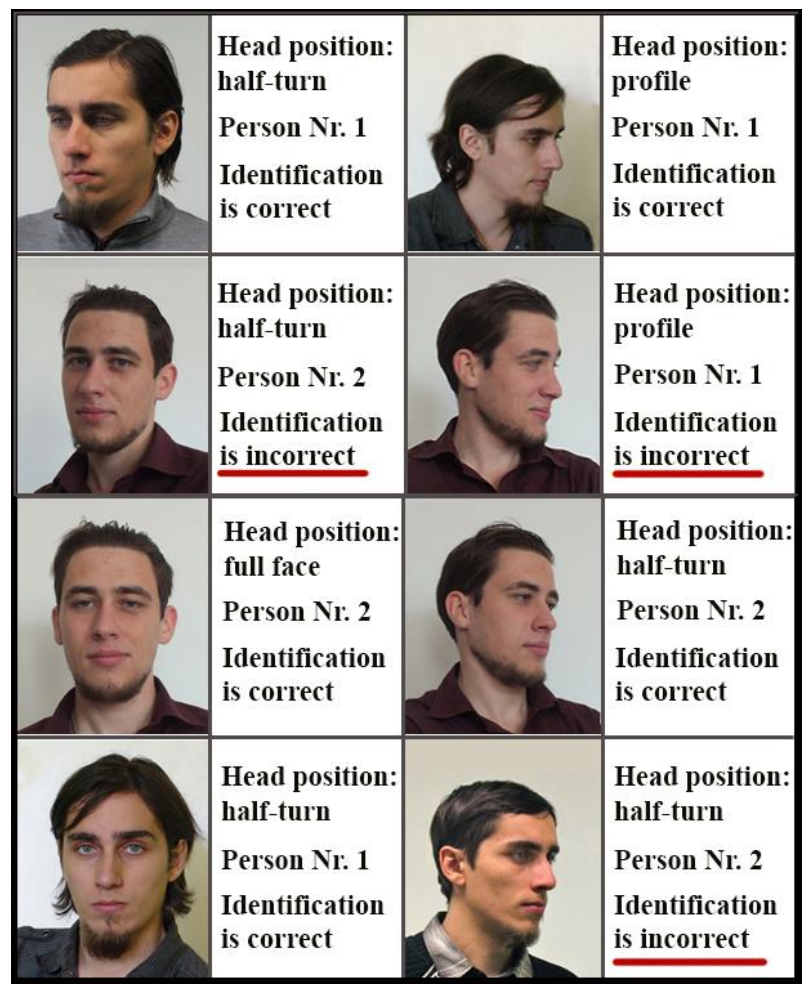

Fig. 13. Face recognition results using the original training set.

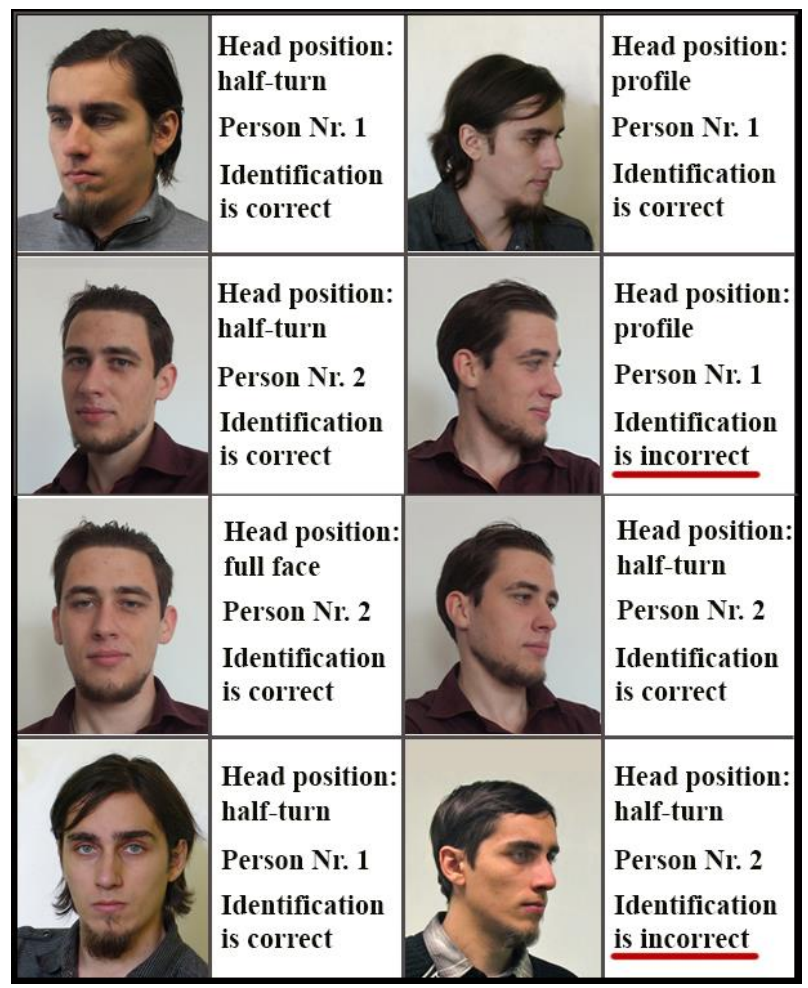

Fig. 14. Face recognition using the extended training set. 


\section{CONCLUSION}

The proposed method of face recognition using of the extended training sample provides higher reliability of face recognition as compared to using only the base training sample. It should be noted, that the efficiency of the proposed method can be increased by additionally extending the training sample (including the new images obtained by rotating the 3D model).

In the future work it is planned to automate the placement of control points on the images of faces that are created by turning the 3D model of a head at different angles.

It is also planned to increase the amount of classes (new faces) in the data base to test the algorithm.

\section{REFERENCES}

[1] M. Turk, A. Pentland, "Face recognition using eigenfaces," Proc. CVPR, 1991, pp. 586-591. http://dx.doi.org/10.1109/CVPR.1991.139758

[2] D. Briljuk, "Raspoznavanie cheloveka po izobrazheniju lica i nejrosetevye metody," D. Briljuk, V. Starovojtov. - Minsk: Institut Tehnicheskoj Kibernetiki Nacional'noj Akademii Nauk Belarusi, 2001.

[3] P. Viola, M. Jones, "Rapid object detection using a boosted cascade of simple features," IEEE Conf. on Computer Vision and Pattern Recognition, Kauai, Hawaii, USA, 2001, vol. 1, pp. 511-518. http://dx.doi.org/10.1109/CVPR.2001.990517

[4] Y.-Q. Wang, "An Analysis of the Viola-Jones face detection algorithm," CMLA, ENS Cachan, France, 2014, pp. 128-148. http://dx.doi.org/10.5201/ipol.2014.104

[5] P. Viola, M. Jones, "Robust real-time face detection," International Journal of Computer Vision, 2004, vol. 57(2), pp. 137-154. http://dx.doi.org/10.1023/B:VISI.0000013087.49260.fb

[6] D. I. Samal, V. V. Starovojtov, "Podhody i metody raspoznavanija ljude po fotoportretam," Minsk, 1998. - 54 s. (Preprint / In-t tehn. kibernetiki NAN Belarusi; №. 8).

[7] V. Starovoitov, D. Samal, G. Votsis, S. Kolias, "Geometric features for face recognition," Proc. PRIP'99, Minsk, Belarus, May 18-20, 1999.

[8] E. Abay, L. Akarum, E. Alpaydyn, "A comparative analysis of different feature sets for face recognition," Proceedings ISCIS, Antalya, 1997.

[9] R. Brunelli, T. Poggio, "Face recognition: features versus templates," IEEE Transactions on Pattern Analysis and Machine Intelligence, 1993 vol. 15, no. 10, pp. 1042-1052. http://dx.doi.org/10.1109/34.254061
[10] S. Lawrence, C. L. Giles, A. C. Tsoi, A. D. Back, "Face recognition: a convolutional neural network approach," IEEE Transactions on Neural Networks, Special Issue on Neural Networks and Pattern Recognition, 1997, vol. 8, no. 1, pp. 98-113. http://dx.doi.org/10.1109/72.554195

[11] O. Krutikova, A. Glazs, "Development of a New Method for Adapting a 3D Model from a Minimum Number of 2D Images," Technologies of Computer Control, 2013, vol.14, pp. 12-17. ISSN 2255-9108. e-ISSN 2255-9116.

[12] O. Krutikova, A. Glazs, "3D model creation based on 2D images," Biomedical Engineering 2013, Proceedings of international conference, Kaunas, Lithuania, 2013, pp. 101-104.

[13] W. K. Pratt, Digital image processing: PIKS Scientific inside, 4th edition, John Wiley \& Sons, Inc., 2007, p. 808, ISBN: 978-0-471-76777-0.

[14] G. Borgefors, "Distance transformations in arbitrary dimensions," Comput. Vis. Graph. Image Proc. 27, 1984, pp. 321-345. http://dx.doi.org/10.1016/0734-189X(84)90035-5

[15] K. Black, A. Ryan, J. Foley, K. Richer, M. Haese, Cambridge IGCSE International Mathematics (0607) Extended EXAM PREPARATION \& PRACTICE GUIDE, 2011, pp. 152, ISBN-13:978-1-921500-16-9.

[16] M. J. Kataev, N. V. Kovalev, A. A. Griboedov, "Vosstanovlenie uglov povorota golovy cheloveka po izobrazhenijam," zhurnal "Doklady Tomskogo gosudarstvennogo universiteta sistem upravlenija $i$ radiojelektroniki" 2012, № 2 (26), chast 1, Tomsk str. 238-242.

Olga Krutikova was born in Riga, Latvia, January 8, 1988. She is a $\mathrm{PhD}$ student at the Faculty of Computer Science and Information Technology, Riga Technical University.

She received the degree of Master of Engineering Sciences from Riga Technical University in 2012.

E-mail: Olga.Krutikova@rtu.lv

Aleksandrs Glazs was born in Riga, Latvia, April 7, 1939. He is a Professor with the Faculty of Computer Science and Information Technology, Deputy Director of the Institute of Computer Control, Automation and Computer Engineering and Head of Image Processing and Computer Graphics Division, Riga Technical University.

He received the Degree of Candidate of Technical Sciences from Riga Polytechnical Institute in 1971 and the Degree of Doctor of Technical Sciences (Dr.habil. sc. ing.) from the Russian Academy of Science in Moscow in 1992. He is the author of more than 100 scientific publications in different areas: pattern recognition, image processing, computer vision and computer graphics.

A. Glazs is a full member of the Baltic Informatization Academy.

Address: Meza Street 1, Riga LV-1048, Latvia.

E-mail: glaz@egle.cs.rtu.lv

Olga Krutikova, Aleksandrs Glazs. Sejas 3D modẹ̣a pielietošana apmācības izlases palielināšanai seju atpazišanas uzdevumos

Cilvēka sejas atpazī̌sana ir aktuāls uzdevums dažāāās sfêrās (kriminālistikā, apsardzes sistēmās un videonovērošanas sistēmās u.c.). Esošajiem 2D seju atpazišanas algoritmiem ir neatrisinātas problēmas, īpaši gadījumos, kad tiek klasificētas līdzīgas sejas.

Šajā rakstā tiek aplūkota pusautomātiskā metode, kura ḷauj atpazīt līdzīgas sejas. Piedāvātajā metodē tika veidots galvas trīsdimensiju modelis, balstoties uz minimālo ieejas attēlu skaitu (sānskats, pretskats un puspagrieziena attēls). Uz katra attēla tika izvietoti kontrolpunkti. Iegūtais modelis tika pagriezts par 20 un 50 grādiem, un iegūti papildus sejas attēli, kas deva iespēju palielināt apmācošu izlasi ar jaunu informāciju par sejas formu. Uz attēliem, kuri tika iegūti, izmantojot 3D modeli, arī tika izvietoti kontrolpunkti. Atpazīšanas procedūra sastāvēja no diviem posmiem: 1) galvas pozīcijas noteikšana un 2) "tuvāka kaimiṇa" meklēšana datubāzē atkarībā no galvas pagrieziena leņ̧̣a un kontrolpunktu attāluma attiecības. Piedāvāto metodi testēja ar astoniem attēliem, kuri iekḷāiva sevī divu cilvēku sejas. Kā parādīja eksperimenta rezultāti, pielietojot paplašinātu apmācības izlasi, piedāvātā metode spēj sekmīgi paveikt uzdevumu un pareizi atpazīt 6 sejas no 8 eksperimentiem, bet gadījumā, kad tika pielietota minimāla apmācības izlase, tad pareizu rezultātu skaits bija tikai 5 no 8 eksperimentiem. No šiem rezultātiem var secināt par paplašinātas apmācības izlases pielietošanas efektivitāti. Šīs metodes galvenā priekšrocība, ka tā neprasa dārgu aparatūru, lai adaptētu sejas trīsdimensiju modeli, kā arī dod iespēju paplašināt apmācības izlasi ar papildinformāciju par sejas formu.

Ольга Крутикова, Александр Глаз. Применение 3D модели лица для увеличения объема обучающей выборки в задачах распознавания лиц. Распознавание лиц является актуальной задачей во многих сферах (криминалистика, охранные системы и системы видеонаблюдения и т.д.). У существующих 2D алгоритмов распознавания лиц есть нерешенные проблемы, особенно в случаях, когда классифицируются похожие лица. В данной статье предлагается полуавтоматический метод, который позволяет распознавать похожие лица. В предложенном методе создавалась трехмерная модель головы по минимальному количеству исходных изображений. На каждом изображении расставлялись контрольные точки. Модель была повернута на 20 и 50 градусов, и получены дополнительные изображения лица, что позволило увеличить объем обучающей выборки с помощью новой информации о форме лица. На изображениях, полученных с помощью 3D модели, также расставлялись контрольные точки. Процедура распознавания состояла из двух этапов: 1) определение позиции головы и 2) поиск «ближайшего соседа» в базе данных в зависимости от угла поворота головы и отношения расстояний между контрольными точками.

Предложенный метод тестировался на восьми изображениях, которые включали в себя лица двух человек. Как показывают результаты экспериментов, применяя расширенную обучающую выборку, предложенный метод смог успешно справиться с задачей и правильно распознать 6 лиц из 8 экспериментов, а в случае когда была применена минимальная обучающая выборка, тогда количество правильных результатов было только 5 из 8 экспериментов. Эти результаты позволяют сделать вывод об эффективности применения расширенной обучающей выборки. Главное преимущество предложенного метода заключается в том, что он не требует дорогого оборудования для адаптации ЗД модели лица, а так же позволяет расширить объем обучающей выборки с помощью новой информации о форме лица. 